\title{
INFORMASI AKUNTANSI DIFERENSIAL SEBAGAI ALAT PENGAMBILAN KEPUTUSAN MENYEWA ATAU MEMBELI GEDUNG PADA PT. BPR MILLENIA KANTOR CABANG PAAL DUA
}

\author{
Miranda Ellora Kotambunan ${ }^{1}$, Grace B. Nangoi ${ }^{2}$, Winston Pontoh ${ }^{3}$ \\ 1, 2,3 Jurusan Akuntansi, Fakultas Ekonomi dan Bisnis, Universitas Sam Ratulangi, Jl. Kampus Bahu, Manado, \\ 95115, Indonesia
}

E-mail: mirandakotambunan18@gmail.com

\begin{abstract}
Decision making is the selection of one of the various alternative actions available. In choosing an alternative, management requires precise and accurate information to reduce the possibility of failure of decisions that will be taken by the company. Differential accounting information is very suitable to be used in the selection of several alternatives. The purpose of this study is to determine whether differential accounting information can be used as a decision-making tool so that companies can decide whether to rent or buy a building as a place to operate its branch offices. This research uses descriptive qualitative method by collecting data through interviews and documentation. The results showed that differential accounting information as a decision-making tool can be applied at PT. BPR Millenia Paal Dua Branch Office and the cost to rent a building is lower than buying a building.

Keywords: differential accounting information; decision-making; leasing; buying.
\end{abstract}

\section{PENDAHULUAN}

Bank yang menjadi lembaga keuangan untuk menghimpun dan menyalurkan dana bagi masyarakat harus mempertahankan eksistensinya. Salah satu cara yang dapat dilakukan oleh bank untuk menghadapi persaingannya yaitu mengembangkan diri lewat adanya perluasan usaha. Perluasan usaha dapat dilakukan dengan membuka atau memiliki kantor cabang di wilayah yang dinilai strategis. Sehubungan dengan itu, perusahaan memerlukan gedung kantor yang dapat dijadikan sebagai tempat kegiatan operasional perusahaan. Hal ini menuntut manajemen untuk membuat keputusan dengan memperhatikan risiko atau ketidakpastian yang akan dihadapi perusahaan nantinya dikarenakan perusahaan akan mengeluarkan dana yang besar. Risiko ini dapat merugikan perusahaan sehingga dalam membuat keputusan, pihak manajemen harus merencanakannya dengan sebaik-baiknya.

Pada dasarnya perencanaan merupakan fungsi dasar dari fungsi manajemen, dimana pihak manajemen akan diperhadapkan pada pengambilan keputusan yang menyangkut berbagai alternatif sehingga memerlukan informasi yang tepat dan akurat guna mengurangi ketidakpastian atas alternatif yang nantinya akan dipilih (Daulay et al., 2019). Sodikin (2015:7) menyatakan bahwa pengambilan keputusan adalah proses untuk memilih salah satu atau beberapa dari tindakan-tindakan alternatif yang berhubungan dengan masa depan perusahaan. Indriani (2018:2) menyatakan bahwa informasi akuntansi manajemen dapat memberikan informasi keuangan bagi manajemen untuk pengambilan keputusan ekonomi dalam melaksanakan fungsi manajemen. Informasi akuntansi manajemen terdiri dari informasi akuntansi penuh (full accounting information), informasi akuntansi diferensial (differential accounting information), dan informasi akuntansi pertanggungjawaban (responsibility accounting information). Terkait adanya pemilihan salah satu di antara alternatif tindakan yang tersedia, manajemen dapat menggunakan informasi akuntansi diferensial yang cocok digunakan dalam pemilihan dari beberapa alternatif. 
PT. Bank Perkreditan Rakyat (BPR) Millenia Manado merupakan salah satu lembaga keuangan yang secara konvensional melayani deposito, tabungan, dan kredit. PT. BPR Millenia Manado memutuskan untuk memperluas usahanya dengan membuka kantor cabang yang terletak di wilayah Paal Dua sehingga didirikan PT. BPR Millenia Kantor Cabang Paal Dua sebagai wujud pengembangan perusahaan guna mendapatkan nasabah. Sejak berdiri, PT. BPR Millenia Kantor Cabang Paal Dua belum memiliki gedung kantor sendiri disebabkan perusahaan selalu menyewa gedung untuk menjadi tempat kegiatan operasionalnya. Gedung kantor yang menjadi tempat kegiatan operasional PT. BPR Millenia Kantor Cabang Paal Dua saat ini masih berstatus sewa dan berakhir pada 31 Oktober 2019. Perusahaan diperhadapkan dengan pengambilan keputusan terkait dengan kebutuhan akan gedung kantor yaitu memilih akan menyewa atau membeli gedung. Selain itu, pengambilan keputusan terutama terkait aktiva tetap harus didasarkan pada pertimbangan ekonomis atau apakah suatu usulan alternatif layak atau tidak untuk dilaksanakan yang dapat dinilai dengan menggunakan metode-metode penilaian investasi. Penelitian ini mengacu pada penelitian Lembong et al., (2018) tentang penentuan keputusan investasi dengan menggunakan informasi akuntansi diferensial dan penelitian Salasa et al. (2018) tentang informasi akuntansi diferensial dalam pengambilan keputusan penggantian aktiva tetap.

\section{TINJAUAN PUSTAKA}

Sodikin (2015:2) menjelaskan bahwa informasi akuntansi manajemen menghasilkan informasi yang berguna bagi manajemen dalam melaksanakan fungsi-fungsinya seperti perencanaan dan pengambilan keputusan. Menurut Indriani (2018:3), informasi akuntansi manajemen dibagi menjadi tiga tipe informasi: informasi akuntansi penuh (full accounting information), informasi akuntansi diferensial (differential accounting information), dan informasi akuntansi pertanggungjawaban (responsibility accounting information). Salasa et al. (2018) menyatakan bahwa informasi akuntansi manajemen yang berhubungan dengan objek informasi berupa produk departemen dan aktivitas perusahaan maka akan dihasilkan informasi akuntansi penuh. Jika dihubungkan dengan wewenang yang dimiliki oleh manajer maka akan dihasilkan informasi akuntansi pertanggungjawaban. Apabila informasi akuntansi manajemen dihubungkan dengan alternatif yang akan dipilih, maka akan dihasilkan informasi akuntansi diferensial.

Indriani (2018:5) menyebutkan bahwa akuntansi diferensial menyajikan informasi taksiran pendapatan, biaya dan atau aktiva berbeda jika suatu tindakan tertentu dipilih, dibandingkan dengan alternatif tindakan yang lain. Sujarweni (2019:7) menjelaskan bahwa informasi akuntansi diferensial merupakan informasi yang dibuat untuk memilih salah satu alternatif pilihan pada perusahaan. Pemilihan masing-masing alternatif yang berbeda akan memberikan pengaruh terhadap kinerja perusahaan (Pinontoan et al., 2020). Akuntansi manajemen akan melakukan perhitungan yang menghasilkan informasi beberapa alternatif kegiatan tersebut. Menurut The dan Sugiono (2015:11), informasi akuntansi diferensial mempunyai dua unsur pokok yaitu merupakan informasi masa yang akan datang dan berbeda diantara alternatif yang dihadapi oleh pengambil keputusan. Informasi ini membantu manajemen menganalisis tiap-tiap alternatif yang akan dihadapi dalam pengambilan keputusan (Tilaar et al., 2015).

Panjaitan dan Sabijono (2015) menyatakan bahwa biaya diferensial dan pendapatan diferensial merupakan informasi penting untuk menilai kelayakan ekonomis suatu rencana alternatif. Menurut Sodikin (2015:133), biaya diferensial merupakan biaya yang akan terjadi di masa depan yang berbeda antara dua alternatif atau lebih. Menurut The dan Sugiono (2015:112), pendapatan diferensial adalah jumlah kenaikan atau penurunan dari jumlah pendapatan yang diharapkan yang dibandingkan dengan alternatif. Tujuan pengambilan keputusan oleh pihak manajemen dengan menggunakan informasi akuntansi diferensial yaitu 
untuk menentukan laba diferensial, jumlah perbedaan atau selisih antara pendapatan diferensial dan biaya diferensial.

Menurut Fauzi dan Irviani (2018:88), pengambilan keputusan adalah proses dalam mengenali masalah-masalah dan peluang-peluang untuk kemudian dipecahkan, sedangkan Sodikin (2015:132) menjelaskan bahwa pengambilan keputusan (decision making) adalah memilih salah satu di antara berbagai alternatif tindakan yang ada. Biswan dan Sinabutar (2018) menyatakan bahwa dalam menentukan mana yang termasuk biaya relevan dan tidak relevan menjadi salah satu hal yang diperlukan pada proses pengambilan keputusan. Biaya relevan pada konteks pengambilan keputusan berupa biaya yang berbeda pada berbagai alternatif pengambilan keputusan yang akan dipilih.

Menurut PSAK No. 16 par. 06 (Ikatan Akuntan Indonesia, 2018), aktiva tetap adalah tanah, gedung atau bangunan, mesin-mesin, kendaraan. Darmanto et al. (2016) menyatakan bahwa informasi akuntansi manajemen dan pengambilan keputusan aktiva tetap saling berkaitan dan bermanfaat karena informasi akuntansi manajemen dapat mengurangi ketidakpastian dalam pengambilan keputusan. Prananda dan Datu (2016) menyatakan bahwa pengambilan keputusan aktiva tetap seperti gedung akan mengeluarkan dana yang besar bagi perusahaan sehingga harus mempertimbangkan usulan alternatif yang baru apakah akan diterima atau ditolak. Jika perusahaan salah mengambil keputusan maka akan berdampak buruk bagi kelangsungan hidup perusahaan. Pengambilan keputusan tersebut mempertimbangkan arus kas keluar yang akan dikeluarkan oleh perusahaan dan aliran kas masuk yang akan diperolehnya berkaitan dengan investasi yang akan diambil.

Sebelum perusahaan menetapkan keputusan atas aktiva tetap, perusahaan harus mengetahui kelayakan dari alternatif tindakan yang tersedia dengan menggunakan metode penilaian investasi untuk mengevaluasi usulan alternatif tindakan yang tersedia sehingga perusahaan mengetahui apakah usulan alternatif tersebut dapat diterima atau ditolak (Musthafa, 2017:70). Suliyanto (2010:145) menyatakan bahwa terdapat beberapa metode penilaian investasi, yaitu payback period, net present value, average return of return, dan internal rate of return. Perusahaan lebih sering memilih menggunakan metode net present value (NPV) dikarenakan NPV menghasilkan keputusan yang lebih konsisten atau sama meskipun adanya perubahan tingkat diskonto (Yasuha dan Saifi, 2017). Metode NPV memperhitungkan nilai waktu uang atau uang yang tersedia pada saat ini bernilai lebih dari jumlah yang sama di masa depan. Jika suatu usulan alternatif menghasilkan NPV $>0$ atau positif, maka usulan alternatif tersebut layak diterima karena alternatif yang memiliki NPV positif akan memberikan keuntungan besar bagi perusahaan, sebaliknya apabila usulan alternatif menghasilkan NPV $<0$ atau negatif, maka usulan alternatif tersebut tidak layak diterima atau sebaiknya ditolak oleh perusahaan (Harjito dan Martono, 2011:145).

\section{METODE PENELITIAN}

Jenis penelitian yang digunakan dalam penelitian ini adalah penelitian kualitatif dengan pendekatan deskriptif yang memberikan gambaran secara umum mengenai bagaimana informasi akuntansi diferensial sebagai alat pengambilan keputusan menyewa atau membeli gedung pada PT. BPR Millenia Kantor Cabang Paal Dua. Objek penelitian ini dilaksanakan di PT. BPR Millenia Kantor Cabang Paal Dua yang beralamat di Kompleks Pasar Segar Blok RB No.07 Paal Dua.

Penelitian ini menggunakan data kualitatif yaitu dengan melakukan pengamatan, pencatatan dan wawancara secara langsung di PT. BPR Millenia Kantor Cabang Paal Dua. Sumber data yang digunakan dalam penelitian ini adalah data primer dan data sekunder, dimana data primer didapat langsung dari hasil dokumentansi dan wawancara langsung dengan pihak PT. BPR Millenia Kantor Cabang Paal Dua. Data sekunder diperoleh dengan cara telaah mendalam melalui dokumen serta referensi lainnya yang didapatkan dari buku dan 
jurnal yang relevan dengan penelitian ini. Metode analisis data yang digunakan adalah metode deskriptif dengan analisis informasi akuntansi diferensial atas perbandingan biaya sewa gedung atau membeli gedung.

\section{HASIL PENELITIAN DAN PEMBAHASAN \\ 4.1. Hasil penelitian}

PT. BPR Millenia Kantor Cabang Paal Dua belum memiliki gedung kantor operasional sendiri. Gedung kantor yang berlokasi di Kompleks Pasar Segar Blok RB No.07 merupakan gedung yang disewa oleh pihak bank untuk menjadi tempat kegiatan operasionalnya dengan masa sewa untuk jangka waktu 1 (satu) tahun dan berakhir pada 31 Oktober 2019 sehingga perusahaan diperhadapkan dalam permasalahan untuk mengambil keputusan berkaitan dengan kebutuhan akan gedung kantor. PT. BPR Millenia Kantor Cabang Paal Dua yang berfungsi menyalurkan dan menghimpun dana masyarakat berencana untuk tetap berada di Kompleks Pasar Segar dikarenakan lokasi saat ini dinilai strategis dan untuk mempermudah nasabah. Berkaitan dengan itu, perusahaan dapat memilih beberapa alternatif yang berkaitan dengan pengadaan gedung kantor, yaitu: (1) menyewa gedung selama periode tertentu; atau (2) membeli gedung.

Pengambilan keputusan aktiva tetap pada PT. BPR Millenia Kantor Cabang Paal Dua dimulai dari pihak kantor cabang mengumpulkan data-data terkait berupa informasi harga sewa dan harga beli gedung ruko yang terbaru dari pemilik gedung ruko. Setelah data tersebut dirangkum dan diolah kemudian diajukan oleh Pimpinan Cabang kepada kantor pusat yang berwenang untuk memutuskan pada kantor cabang yaitu dalam hal ini Dewan Direksi untuk disetujui dan direalisasikan. PT. BPR Millenia Kantor Cabang Paal Dua memutuskan untuk tetap menempati ruko yang sama dengan spesifikasi gedung ruko sebagai berikut:

1. Luas tanah

2. Luas bangunan

: $56,25 \mathrm{~m}^{2}$

3. Jumlah lantai

$112 \mathrm{~m}^{2}$

4. Kualitas bangunan

2 lantai

5. Sumber air

: Baik dan terawat

: Perusahaan Daerah Air Minum/PT. Air Manado

6. Instalasi listrik terpasang : $6.600 \mathrm{KwH}$

Berdasarkan hasil penelitian pada PT. BPR Millenia Kantor Cabang Paal Dua dapat diketahui bahwa harga sewa untuk ruko sesuai spesifikasi adalah Rp. 50.673.101 per tahun. Biaya yang dikeluarkan untuk kegiatan operasional perusahaan selama setahun adalah sebesar Rp. 375.895.298. Biaya operasional pada PT. BPR Millenia Kantor Cabang Paal Dua berupa biaya penyisihan kerugian, biaya pemasaran, biaya administrasi dan umum. Apabila perusahaan akan membeli ruko yang sama dengan yang telah disewa maka harga beli tanah dan bangunan ruko yang memiliki spesifikasi sejenis bernilai Rp. 925.000 .000 yang telah disesuaikan dengan harga pasar terkini dan biaya yang akan dikeluarkan oleh perusahaan untuk kegiatan operasional jika perusahaan akan membeli gedung yaitu sebesar Rp. 325.222.197. Biaya operasional untuk membeli gedung, tidak termasuk dengan biaya sewa yang akan dikeluarkan selama setahun yaitu sebesar Rp. 50.673.101.

\subsection{Pembahasan}

Perusahaan membutuhkan informasi yang tepat dan sesuai untuk menentukan alternatif terbaik dari beberapa alternatif yang tersedia. Informasi akuntansi diferensial yang berhubungan dengan pemilihan dari beberapa alternatif dapat membantu perusahaan didalam menetapkan keputusan khususnya dalam memilih untuk menyewa atau membeli gedung. Tabel 1 menyajikan penghitungan laba diferensial selama 25 tahun kepemilikan gedung. 
Tabel 1. Laba diferensial selama 25 tahun kepemilikan gedung

\section{Pendapatan Diferensial :}

Penghematan biaya operasional dari sewa gedung

\section{Biaya Diferensial :}

Biaya operasional atas kepemilikan gedung

Sumber: Data olahan, 2019

Berdasarkan Tabel 1 dapat diketahui bahwa laba diferensial diperoleh dari selisih jumlah penghematan biaya operasional dari sewa gedung dengan biaya operasional atas kepemilikan gedung pada PT. BPR Millenia Kantor Cabang Paal Dua yang berjumlah Rp. 50.673.101. Jika dilihat dari hasil analisis data maka keputusan untuk menyewa gedung merupakan keputusan yang terbaik bagi perusahaan saat ini disebabkan adanya penghematan biaya operasional dari sewa gedung sebesar Rp. 375.895.298 dan biaya yang dikeluarkan untuk menyewa gedung lebih rendah daripada akan membeli gedung.

PT. BPR Millenia Kantor Cabang Paal Dua perlu melakukan adanya perhitungan penilaian investasi untuk mengetahui kelayakan dari alternatif yang akan dipilih. Setelah perusahaan mengetahui laba diferensial selama 25 tahun, maka selanjutnya perusahaan akan menentukan tingkat pengembalian investasi atau return on investment (ROI). Adanya return on investment (ROI) maka perusahaan dapat memperhatikan efektivitas pemanfaatan modal untuk kepentingan investasi dan seberapa besar laba yang akan dihasilkan (Hilton dan Platt, 2017:557). Return on investment (ROI) dapat dihitung dengan cara :

$$
\text { ROI }=\frac{\text { Laba diferensial }}{\text { Investasi }}
$$

Perusahaan akan mengeluarkan nilai investasi sebesar Rp. 925.000.000, maka tingkat pengembalian investasi berdasarkan rata-rata laba diferensialnya selama 25 tahun atau berjumlah Rp. 50.673.101 adalah sebesar 5,5\%. Penghitungan tingkat pengembalian investasi atau return on investment (ROI) adalah sebagai berikut.

$$
\begin{aligned}
\text { ROI } & =\frac{50.673 .101}{925.000 .000} \\
& =5,5 \%
\end{aligned}
$$

Selanjutnya, perusahaan akan melakukan penghitungan tarif pengembalian investasi dengan jangka waktu yang diharapkan untuk pengembalian investasi yang dikeluarkan adalah selama 25 tahun, maka penentuan tarif pengembalian dapat dilakukan dengan menggunakan rumus metode nilai waktu sekarang atau Net Present Value.

$$
\frac{1}{(1+n) i}
$$

Berdasarkan metode nilai waktu sekarang diketahui bahwa $\mathrm{n}$ adalah tingkat pengembalian investasi (ROI), sedangkan i adalah tahun. Penggunaan metode nilai waktu sekarang atau Net Present Value bertujuan untuk mengetahui nilai tunai yang akan diperoleh atas hasil pengembalian investasi yang telah diproyeksi pada masa sekarang. Nilai waktu sekarang membantu perusahaan untuk memilih keputusan terkait investasi yang tepat bagi 
pengembangan atau keberlanjutan perusahaan yaitu keputusan untuk menerima atau menolak investasi yang akan dibutuhkan perusahaan (Pontoh dan Budiarso, 2020). Tabel 2 menyajikan perhitungan nilai tunai laba diferensial berdasarkan waktu yang diperoleh dengan menggunakan tarif pengembalian yang telah diperoleh sehingga perusahaan dapat memperoleh jumlah keseluruhan dari pengembalian atas investasi yang akan dikeluarkan.

Tabel 2. Perhitungan nilai tunai laba diferensial

\begin{tabular}{|c|c|c|c|}
\hline Tahun & $\begin{array}{l}\text { Laba diferensial } \\
(\mathbf{R p}) \\
(\mathbf{1})\end{array}$ & $\begin{array}{c}\text { Tarif } \\
\text { Pengembalian } \\
\text { (2) }\end{array}$ & $\begin{array}{l}\text { Nilai Tunai Laba Diferensial } \\
(\mathbf{R p}) \\
(3)=(1) \times(2)\end{array}$ \\
\hline 1 & 50.673 .101 & 0,9479 & 48.031 .375 \\
\hline 2 & 50.673 .101 & 0,8985 & 45.527 .370 \\
\hline 3 & 50.673 .101 & 0,8516 & 43.153 .905 \\
\hline 4 & 50.673 .101 & 0,8072 & 40.904 .176 \\
\hline 5 & 50.673 .101 & 0,7651 & 38.771 .730 \\
\hline 6 & 50.673 .101 & 0,7252 & 36.750 .455 \\
\hline 7 & 50.673 .101 & 0,6874 & 34.834 .555 \\
\hline 8 & 50.673 .101 & 0,6516 & 33.018 .535 \\
\hline 9 & 50.673 .101 & 0,6176 & 31.297 .190 \\
\hline 10 & 50.673 .101 & 0,5854 & 29.665 .583 \\
\hline 11 & 50.673 .101 & 0,5549 & 28.119 .036 \\
\hline 12 & 50.673 .101 & 0,5260 & 26.653 .115 \\
\hline 13 & 50.673 .101 & 0,4986 & 25.263 .616 \\
\hline 14 & 50.673 .101 & 0,4726 & 23.946 .555 \\
\hline 15 & 50.673 .101 & 0,4479 & 22.698 .157 \\
\hline 16 & 50.673 .101 & 0,4246 & 21.514 .840 \\
\hline 17 & 50.673 .101 & 0,4024 & 20.393 .214 \\
\hline 18 & 50.673 .101 & 0,3815 & 19.330 .060 \\
\hline 19 & 50.673 .101 & 0,3616 & 18.322 .332 \\
\hline 20 & 50.673 .101 & 0,3427 & 17.367 .139 \\
\hline 21 & 50.673 .101 & 0,3249 & 16.461 .743 \\
\hline 22 & 50.673 .101 & 0,3079 & 15.603 .548 \\
\hline 23 & 50.673 .101 & 0,2919 & 14.790 .093 \\
\hline 24 & 50.673 .101 & 0,2767 & 14.019 .046 \\
\hline 25 & 50.673 .101 & 0,2622 & 13.288 .195 \\
\hline
\end{tabular}

Sumber : Data olahan, 2019

Tabel 2 menunjukkan bahwa jumlah keseluruhan nilai tunai laba diferensial adalah sebesar Rp. 679.725.564, sehingga jika dibandingkan dengan jumlah investasi untuk membeli gedung Rp. 925.000.000, maka PT. BPR Millenia Kantor Cabang Paal Dua dapat menolak investasi ini. Hal ini disebabkan karena nilai keseluruhan yang akan diterima oleh perusahaan hingga akhir tahun ke-25 kurang sebesar Rp. 13.288.195 dari nilai investasi.

\section{KESIMPULAN DAN SARAN}

\subsection{Kesimpulan}

Berdasarkan hasil penelitian yang dilakukan pada PT. BPR Millenia Kantor Cabang Paal Dua maka dapat diambil kesimpulan yaitu:

1. Penggunaan informasi akuntansi diferensial sebagai alat pengambilan keputusan investasi yang didukung dengan penilaian investasi pada PT. BPR Millenia Kantor Cabang Paal 
Dua dapat membantu perusahaan dalam menetapkan keputusan terbaik diantara pemilihan dari alternatif yang tersedia yaitu menyewa atau membeli gedung.

2. Berdasarkan hasil perhitungan dapat diketahui bahwa laba diferensial diperoleh dari selisih jumlah penghematan biaya operasional dari sewa gedung dengan biaya operasional atas kepemilikan gedung dan keputusan untuk menyewa gedung merupakan keputusan yang terbaik bagi PT. BPR Millenia Kantor Cabang Paal Dua disebabkan biaya yang dikeluarkan untuk menyewa gedung lebih rendah dibandingkan membeli gedung.

3. Hasil perhitungan penilaian investasi dengan menggunakan metode nilai waktu sekarang atau Net Present Value menunjukkan bahwa jumlah keseluruhan nilai tunai laba diferensial adalah sebesar Rp. 679.725.564, sehingga jika dibandingkan dengan jumlah investasi untuk membeli gedung Rp. 925.000.000, maka PT. BPR Millenia Kantor Cabang Paal Dua dapat menolak investasi ini.

\subsection{Saran}

Sebaiknya PT. BPR Millenia Kantor Cabang memilih untuk menyewa gedung pada saat ini. Pengambilan keputusan terkait aktiva tetap yaitu menyewa atau membeli gedung, sebaiknya direncanakan dengan sebaik-baiknya oleh perusahaan. Hal ini dapat memberikan dampak besar bagi perusahaan di masa yang akan datang.

\section{DAFTAR PUSTAKA}

Biswan, A. T., \& Sinabutar, G. P. R. (2018). Pengambilan keputusan manajerial sektor publik: Menyewa, membeli, atau membangun sendiri. Jurnal Substansi, 2(1), 19-38. http://jurnal.pknstan.ac.id/index.php/SUBS/article/view/265

Darmanto, R., Lambey, L., \& Tangkuman, S. (2016). Peran informasi akuntansi manajemen mengenai pengambilan keputusan investasi aktiva tetap pada PT. Anugerah Trikarya Lestari. Jurnal EMBA : Jurnal Riset Ekonomi Manajemen Bisnis dan Akuntansi, 5(1), 215-224. https://ejournal.unsrat.ac.id/index.php/emba/article/view/15543

Daulay, R., Muhyarsyah, M., \& Astuty, W. (2019). The utilization of management differential accounting in decision making regarding fixed asset investment at PDAM Tirtanadi North Sumatera Province. Multi-disciplinary international conference university of asahan 23rd march 2019. Kisaran. http://jurnal.una.ac.id/index.php/seminter2019/article/view/559

Fauzi, H., \& Irviani, R. (2018). Pengantar manajemen, Edisi Revisi. Yogyakarta: Andi.

Harjito, D. A., \& Martono. (2011). Manajemen keuangan, Edisi Kedua. Yogyakarta: Ekonisia.

Hilton, R. W., \& Platt, D. E. (2017). Managerial accounting: Creating value in a dynamic business environment, $11^{\text {th }}$ Edition. United States: McGraw-Hill Education.

Ikatan Akuntan Indonesia. (2018). Pernyataan Standar Akuntasi Keuangan nomor 16 aset tetap. Jakarta: Salemba Empat.

Indriani, E. (2018). Akuntansi manajemen, Edisi 1. Yogyakarta: Andi.

Lembong, E. F., Tinangon, J., \& Tirayoh, V. (2018). Penentuan keputusan investasi dengan menggunakan informasi akuntansi diferensial pada CV. Nyiur Trans Kawanua Manado. Going Concern: Jurnal Riset Akuntansi, 13(2), 503-511. https://doi.org/10.32400/gc.13.02.19674.2018

Musthafa, H. (2017). Manajemen keuangan, Edisi I. Yogyakarta: Andi.

Panjaitan, D. A. K., \& Sabijono, H. (2015). Peranan informasi akuntansi manajemen dalam proses pengambilan keputusan jangka panjang mengenai investasi aktiva tetap pada PT. Cakra Buana Megah. Jurnal EMBA : Jurnal Riset Ekonomi Manajemen Bisnis 
dan Akuntansi, $\quad 3(2), \quad 874-882$.

https://ejournal.unsrat.ac.id/index.php/emba/article/view/8911

Pinontoan, R. F., Pangemanan, S. S., \& Runtu, T. (2020). Penerapan informasi akuntansi diferensial dalam pengambilan keputusan manajemen pada UMKM Gilingan Padi Mekar Sari Desa Kosio Kecamatan Dumoga Tengah. Indonesia Accounting Journal, 2(1), 30-36. https://doi.org/10.32400/iaj.27488

Pontoh, W., \& Budiarso, N. S. (2020). Keputusan investasi pada Usaha Mikro, Kecil, dan Menengah. The Studies of Social Science, 2(1). 27-32. https://doi.org/10.35801/tsss.2020.2.1.27583

Prananda, A. A., \& Datu, C. (2016). Peranan sistem informasi akuntansi manajemen dalam pengambilan keputusan investasi aset tetap pada PT. Etmieco Sarana Laut Bitung. Jurnal EMBA: Jurnal Riset Akuntansi Manajemen Bisnis dan Akuntansi, 4(1). 15311541. https://ejournal.unsrat.ac.id/index.php/emba/article/view/12375

Salasa, J. Y. P., Nangoi, G. B., \& Rondonuwu, S. (2018). Analisis informasi akuntansi diferensial dalam pengambilan keputusan penggantian aktiva tetap pada UD. Singkil Service Manado. Going Concern: Jurnal Riset Akuntansi, 13(4). 867-874. https://doi.org/10.32400/gc.13.04.22064.2018

Sodikin, S. S. (2015). Akuntansi managemen sebuah pengantar, Edisi kelima. Yogyakarta: UPP STIM YKPN.

Sujarweni, V. W. (2019). Akuntansi manajemen: Teori dan aplikasi, Cetakan II. Yogyakarta: Pustaka Baru Press.

Suliyanto. (2010). Studi kelayakan bisnis: Pendekatan praktis, Edisi I. Yogyakarta: Andi.

The, I., \& Sugiono, A. (2015). Akuntansi-Informasi dalam pengambilan keputusan. Jakarta: Grasindo.

Tilaar, H., Karamoy, H., \& Pontoh, W. (2015). Analisis biaya diferensial dalam pengambilan keputusan membeli atau memproduksi sendiri bahan baku daging ayam olahan pada UD. Adi Paslah Manado, Jurnal EMBA: Jurnal Riset Akuntansi Manajemen Bisnis dan Akuntansi, 3(1), 933-940. https://ejournal.unsrat.ac.id/index.php/emba/article/view/7622.

Yasuha, J. X. L., \& Saifi, M. (2017). Analisis kelayakan investasi atas rencana penambahan aktiva tetap (Studi kasus pada PT. Pelabuhan Indonesia III (Persero) Cabang Tanjung Perak Terminal Nilam). Jurnal Administrasi Bisnis, 46(1), 113-121. http://administrasibisnis.studentjournal.ub.ac.id/index.php/jab/article/view/1789 